\title{
The design of OpticalGamification (OG) with random model in learning interference and diffraction
}

\author{
Saprudin Saprudin 1, a *, Liliasari Liliasari 2, b , Ary Setijadi Prihatmanto ${ }^{3, c}$, Andhy Setiawan ${ }^{4, d}$, \\ Fatma Hamid 1, e \\ ${ }^{1}$ Universitas Khairun. Jl. Pertamina Kampus II Gambesi 97719, Indonesia \\ ${ }^{2}$ Universitas Pendidikan Indonesia. Jl. Dr. Setiabudhi No. 229, Bandung 40154, Indonesia \\ ${ }^{3}$ Institut Teknologi Bandung. Jl. Ganesha 10 Bandung 40132, Indonesia \\ ${ }^{4}$ Universitas Pendidikan Indonesia. Jl. Dr. Setiabudhi No. 229, Bandung 40154, Indonesia \\ a saprudin@unkhair.ac.id, b liliasari@upi.edu, casetijadi@lskk.ee.itb.ac.id, dandhys@upi.edu, \\ efatmahamid@unkhair.ac.id \\ * Corresponding Author.
}

Received: 18 November 2020; Revised: 20 December 2020; Accepted: 10 January 2021

\begin{abstract}
This article describes the design and preliminary field testing of using a gamification-application with random model in the learning process of interference and diffraction topics for pre-service physics teachers (PPT). The gamification-application in this research is called OpticalGamification (OG) featuring random model. This research is a quasi-experimental research with a time-series design involving 34 PPT at a university in the city of Jakarta, Indonesia. Data related to the PPT' concept mastery are collected through test instruments in the form of 50 questions which are an integration of multiplechoice questions, reasoned multiple-choice questions, and essays. This research resulted in a product called OG with random model with several features, including profiles, gamification, forums, achievement pages, projects and leaderboard. The result of preliminary field testing of using the OG with random model shows that the PPT' concept mastery has increased from series 1 to the next following series.

Keywords: OpticalGamification (OG), Random model, Interference and diffraction
\end{abstract}

How to Cite: Saprudin, S., Liliasari, L., Prihatmanto, A. S., Setiawan, A., \& Hamid, F. (2021). The design of OpticalGamification (OG) with random model in learning interference and diffraction. Momentum: Physics Education Journal, 5(1), 29-42. https://doi.org/10.21067/mpej.v5i1.4889

\section{Introduction}

Information technology is defined as a technology used for information processing purposes, thus it can be stated that information technology emphasizes information processing aspects to deliver effective communication process (Mukarom \& Rusdiana, 2017). Whereas, communication technology is defined as a technological device (hardware, software, process, system) to assist the communication process, which is used to communicate or being communicative (Munir, 2008), thus communication technology emphasizes on the transmission of information processing results (Mukarom \& Rusdiana, 2017). Behan \& Holmes (Munir, 2012) stated that information and communication technology (ICT) is a technology that supports the activities of recording, storing, processing, retrieving, transmitting/delivering, and receiving information. Following this definition, Mukarom and Rusdiana (2017) states that ICT can be regarded as the use of electronic computing technology in the processing and transmitting of information, therefore information can be more effective to be conveyed to those who need it.

The accuracy of the application of ICT in education is one of the important factors to improve the quality of education and human resources (Munir, 2012). In the context of learning, Rosenberg ( $\mathrm{n}$ 
Mukarom \& Rusdiana, 2017) states that the use of ICT in the learning process causes five shifts including (1) a shift from a training to a performance; (2) a shift from the classroom to another location that does not only last during the learning hours; (3) a shift from paper to online computers/ networks/channels; (4) a shift from physical facilities to working network facilities; and (5) a shift from cycle time to real-time.

The use of ICT applications in learning greatly affects the learning process and it creates different approach from face-to-face learning. For learners and instructors to communicate effectively, active interactions between the two can be done synchronously (interactions occur simultaneously or in real-time) or asynchronously (interactions do not occur at the same time). There are several synchronous and asynchronous learning conditions, including (1) learning at the same time and place (for example, learning in the classroom); (2) learning at different times, but in the same place (learning center, laboratory, and library); (3) learning at the same time, but in different places (audioconferencing, videoconferencing, satellite delivery, chat rooms); and (4) learning at different times and places (learning management system or known by the abbreviation LMS, e-learning).

Along with the rapid development of science and technology, ICT has been used extensively in efforts to increase the effectiveness of learning physics. Some forms of the use of ICT in learning physics include using animation (Gero et al., 2014; Su \& Yeh, 2014), instructional video (Saprudin et al., 2016; Putra \& Sudarti, 2015; Saprudin et al., 2018), interactive simulation (Alrsa'i \& Aldhamit, 2014; Alsultanny et al., 2014; Martínez et al., 2011; Mešić et al., 2015; Onorato et al., 2015; Srisawasdi \& Kroothkeaw, 2014), interactive multimedia (Komarudin et al., 2014; Radlović-Čubrilo et al., 2014; Saprudin \& Hamid, 2018a, 2018b; Saprudin, 2015), virtual laboratory (Collier et al., 2012; Escobar et al., 2016), digital game (Chen et al., 2016; Dorji et al., 2015; Hamari et al., 2016; Saprudin et al., 2017; Saprudin, 2018; Saprudin et al., 2019a; Tsai et alz., 2016; Yang et al., 2016), augmented reality (Putri et al., 2016), e-learning (Agustine et al., 2014; Aminoto \& Pathoni, 2014; Amri et al., 2015; Marwah \& Kustijono, 2015; Yuda et al., 2014), mobile learning (Zhou et al., 2017).

The challenge of ICT-based learning at the implementation stage is how user can be drawn into the system therefore they can be fully engaged in learning on an ongoing basis. One of the reasons why users (students) choose to stop using ICT-based learning media, is not because the learning system is less interactive, but rather because of monotonous presentation and the user's lack of motivation in engaging with the learning process presented through the media. Gamification has the potential to be an alternative solution to solve these problems.

In general, gamification is defined as the use of game design elements in non-game contexts (Deterding et al., 2012, 2011; Mulyana et al., 2016; Saprudin et al., 2019; Saprudin et al., 2020). Gamification refers to the process of improving performance by presenting game-playing experiences to support the overall user's creation value (Huotari \& Hamari, 2012). In other studies, gamification is the use of game mechanics, aesthetics, and gaming mindset to engage people, motivate actions, improve learning, and solve problems (Kapp et al., 2014).

OpticalGamification which is abbreviated as OG is an ICT-based gamification application by applying game design elements in a serious optics context (Saprudin et al., 2020b). This application is intended to be used in the learning process in optics courses, specifically the topic of interferences and diffractions for pre-service physics teachers (PPT). The OG application with random model consists of nine sub-topics and three evaluations. Each sub-topic has been designed into levels that must be done by students. Each level and also the evaluation comprise a minimum score limit that must be achieved by the PPT to get a star reward. The OG with a random model is presented in three sessions, where each session includes three levels and one evaluation.

In the context of learning at university levels, in general, most of the PPT are above 18 years old, hence it can be regarded that they are an adult (Arif, 2012; Dharma, 2015; Tarno, 2017). Andragogy or education for adulthood comprises of several assumptions, specifically: (1) self-concept; there is a shift from someone who depends on others to someone who is independent; (2) Experiences; events experienced can be used as a source of learning by someone who is always developing; (3) readiness to learn; progressively oriented towards developmental tasks and social roles; and (4) orientation towards learning; there is a shift in perspective of knowledge application toward know- 
ledge that can be applied immediately, and there is a shift in the orientation of learning towards problem-centered learning (Arif, 2012).

Based on andragogy theory, the OG application with random model is designed to facilitate diversity in PPT learning behavior. In the OG application with a random model, PPT can study material on several sub-topics with random sequence across various sessions to their likings.

This research will describe the design and result of preliminary field testing of using OG application with random model. This gamification application model is necessary to be developed and studies regarding this topic are still rarely found. Therefore, this research presents its novelty and innovations. Empirical evidence from this research is expected to be an alternative that can be used as a reference material in designing future gamification application models.

\section{Method}

This quasi-experimental research used the time-series design as shown in Table 1. This research involved 34 PPT (Six male and 28 Female with the average age of 20 years old) who took the optics course, studying interference and diffraction topics at one of the universities in Jakarta, during the odd semester of 2018/2019 academic year.

Table 1. Research Design

\begin{tabular}{ccccccc}
\hline $\mathrm{T}_{1}$ & $\mathrm{~T}_{2}$ & $\mathrm{~T}_{3}$ & $\mathrm{X}$ & $\mathrm{T}_{4}$ & $\mathrm{~T}_{5}$ & $\mathrm{~T}_{6}$ \\
\hline
\end{tabular}

$T_{1}, T_{2}$ and $T_{3}$ are the pre-test series 1,2 , and 3 ; whereas $T_{4}, T_{5}$ and $T_{6}$ are post-test series 1,2 , and $3 ; X$ is treatment or intervention in the form of using the OG application with random model.

Data related to the PPT' concept mastery was collected through test instruments in the form of 50 questions which was an integration of multiple-choice questions, reasoned multiple-choice questions, and essays. The increase in PPT' concept mastery was determined by calculating the normalized gain $\langle g\rangle$ using the equation developed by (Hake, 1998), as follow:

$\langle g\rangle=\frac{\%<G>}{\%<G>_{\max }}=\frac{\% S_{f}-\% S_{i}}{100-\% S_{i}}$

The interpretation of $\langle g\rangle$ is presented in Table 2.

Table 2. Interpretation of Normalized Gain

\begin{tabular}{cc}
\hline Value & Category \\
\hline$\langle g\rangle \geq 0.70$ & High \\
$0.70>\langle g\rangle \geq 0.30$ & Medium \\
$\langle g\rangle<0.30$ & Low \\
\hline
\end{tabular}

\section{Results and Discussion}

\section{Design of The OG Application with Random Model}

The OG application with random model consists of nine sub-topics (level) and three evaluations. The home interface and flowchart of the OG application with random model are presented in Figure 1, Figure 2, and Figure 3.

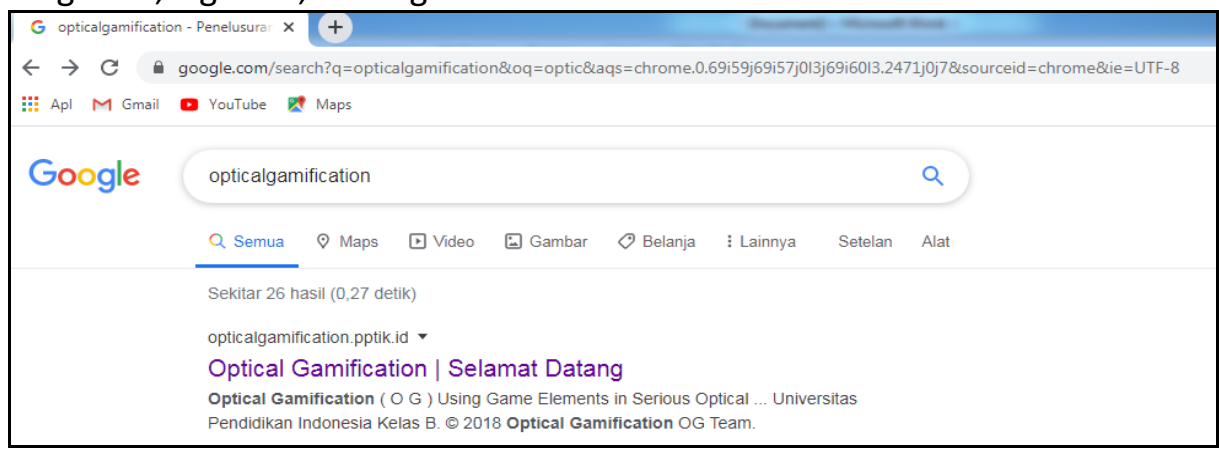

Figure 1. The Display of the OG Application with Random Model on Google Search Result 


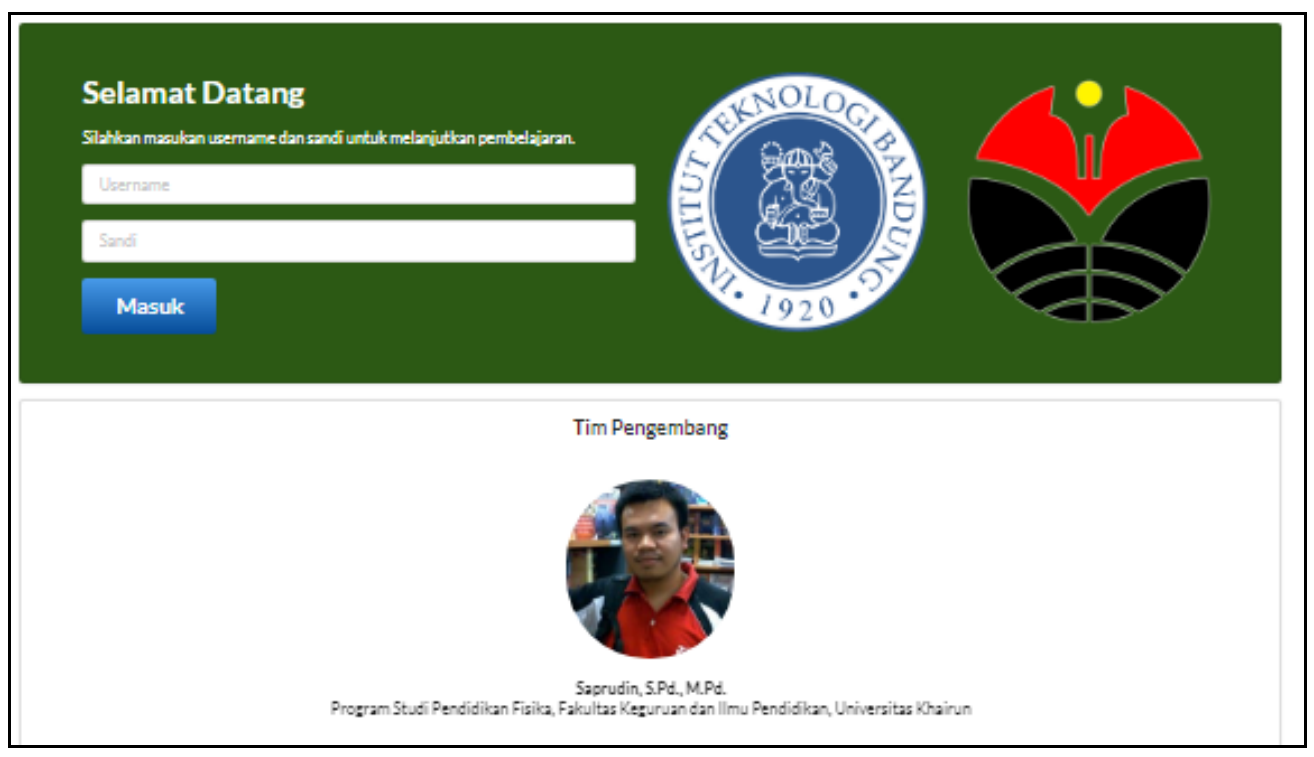

Figure 2. The Home Interface of the OG Application with Random Model

In the OG application with random model, the PPT can learn more than one sub-topic (levels) in a random sequence and also cross-sessions. The PPT are given the freedom to work on the level or the evaluation in any sequence they are choosing. The PPT might successfully pass the learning process of this application when they achieve a score of at least 70 on each evaluation.

\section{The Result of Preliminary Field Testing}

To identify and examine the increase in PPT' concept mastery, an analysis of PPT' pre-test and post-test results was conducted. The initial features of the OG application with random model that were tested in series 1 are shown in Table 3.

Table 3. Initial Features of the OG Application with Random Model

\begin{tabular}{ll}
\hline $\begin{array}{l}\text { Features Development } \\
\text { of the OG Application }\end{array}$ & \multicolumn{1}{c}{$\begin{array}{c}\text { Explanation } \\
\text { Profile }\end{array}$} \\
& $\begin{array}{l}\text { This feature displays a description of PPT' data such as full names, student } \\
\text { identification numbers, instances, and the portrait of PPT who joins the class using } \\
\text { the OG system. } \\
\text { This gamification feature is developed by integrating dependent-experiment quiz, } \\
\text { remedial teaching, and mastery learning. The OG application consists of nine levels } \\
\text { and three evaluations. } \\
\text { This feature displays the ten PPT with the highest scores compared to all PPT who } \\
\text { join the class using the OG system. }\end{array}$ \\
\hline
\end{tabular}

\section{Series 1: The Use of the OG Application with Random Model}

The results of data processing of the pre-test and post-test regarding the PPT' concept mastery for the topic of interference and diffraction in the series 1 are presented in Table 4 . In general, PPT' concept mastery in the series 1 has increased after an intervention which is the use of OG application with random model.

Table 4. Pre and Post Test Results in Series 1

\begin{tabular}{cccccc}
\hline Test & $X_{\text {ideal }}$ & $X_{\max }$ & $X_{\min }$ & $\bar{X}$ & $s$ \\
\hline Pre-test & 16.00 & 11.00 & 4.00 & 7.18 & 1.62 \\
Post-test & 16.00 & 15.00 & 7.00 & 10.76 & 1.92 \\
\hline
\end{tabular}

Based on Figure 4, PPT' concept mastery in series 1 has increased at each level. At level 1 (L1), which is the sub-topic of lightwave characteristics, the PPT' concept mastery before the intervention 
was categorized as medium (58.00\%), then increased into the very high category (82.33\%) after the intervention. This shows that there is a $24.33 \%$ difference in the PPT' concept mastery at level 1.

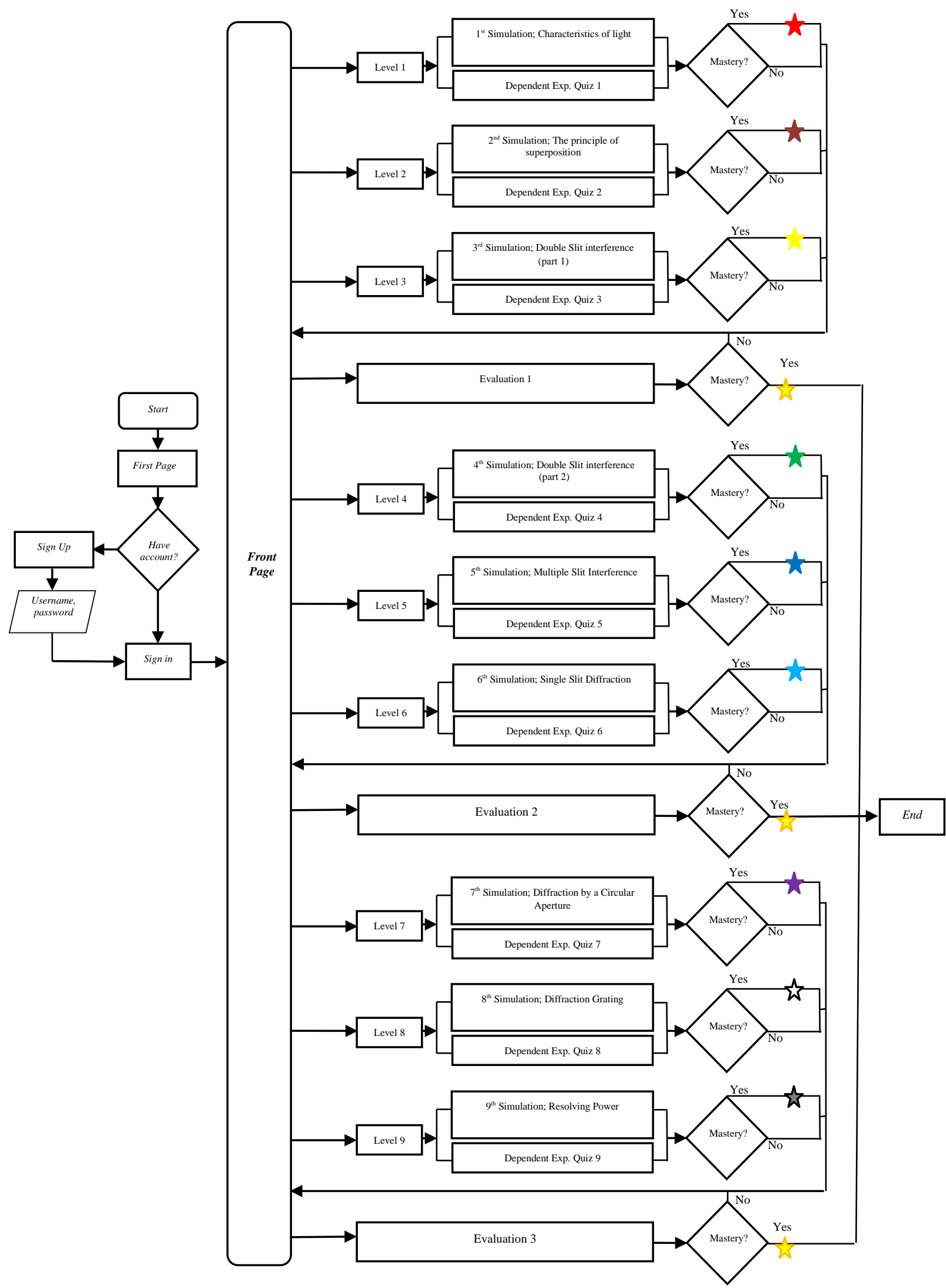

Figure 3. The Flowchart of the OG Application with Random Model 
At level 2 (L2), which is the sub-topic of wave superposition principle, the PPT' concept mastery before the intervention is categorized as low (32.40\%). Whereas after the intervention, the concept mastery is categorized as medium (44.20\%). This shows that there are differences in concept mastery at level 2 by 11.80 percent.

At level 3 (L3), which is the double-slit interference sub-topic (part 1), the PPT' concept mastery before the intervention was considered medium (47.75\%), then increased to the high category (76.13\%) after the intervention. This shows that there are differences in concept mastery at level 3 by 28.38 percent.

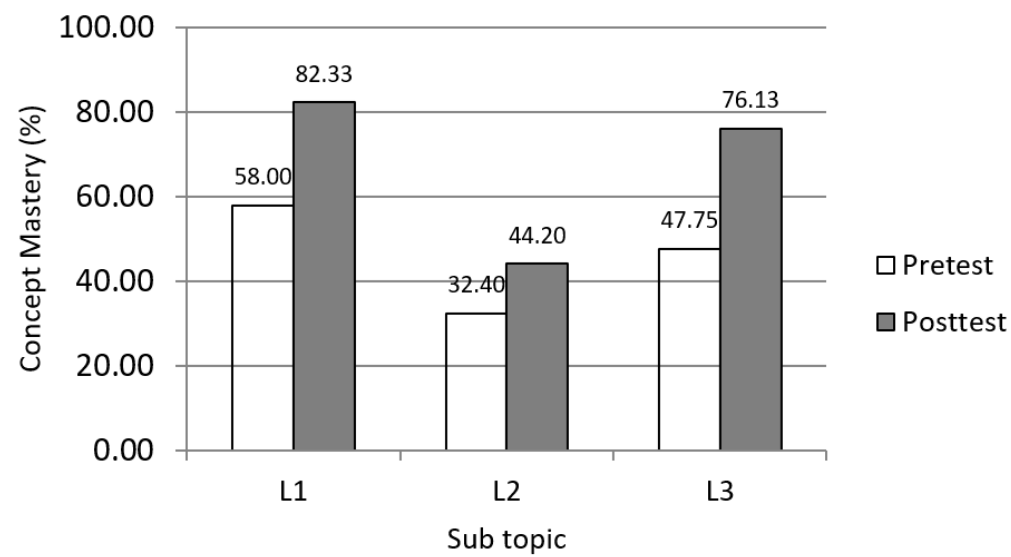

Figure 4. Profile of PPT' Concept Mastery in Series 1

Revision of the OG Application with Random Model on The Series 1

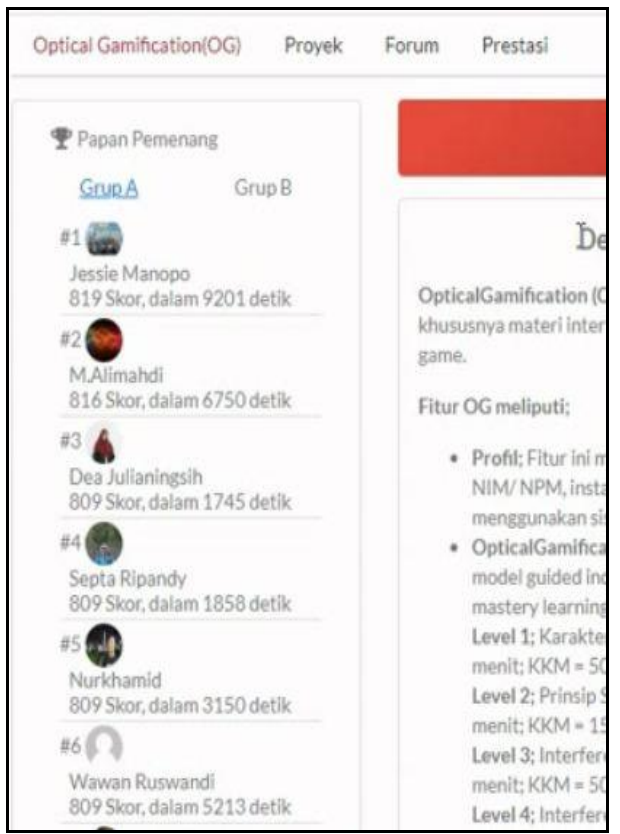

Figure 5. Leaderboard for the 10 PPT with the Highest Score

The revision of the OG application with random model in series 1 was based on findings that can be used as an improvement, including; First, when participating in the learning process using the OG application with random model, numerous challenges were faced by students. To support the effectiveness of learning during series 1 , the means of communication was carried out using WhatsApp. The OG application with random model needs to have a feature that facilitate communication or discussion between the PPT and the lecturers, as well as discussions among the PPT itself. Second, The leaderboard only shows the achievements of ten PPT with the highest score as shown in Figure 5. Because of that, it is felt to be necessary to add a feature that presents the achievements of all PPT joining this course, instead of just the top-ten ranking. A leaderboard that can be accessed by 
all PPT is expected to motivate them to be more engaged in learning activities using the OG application with random model. Third, Some PPT were found to still have a weak ability to use computer applications, and it made them demotivated of participating in learning using OG applications with random model. Fourth, The lecturers ought to monitor the progress of the assignments given to the PPT, thus PPT are expected to complete their assignments on time. Fifth, In a face-to-face situation, the lecturer needs to conduct a reflection on the assignments that the PPT finished by using the OG application with random model, the lecturer guides the PPT to overcome various factors that become challenges when interacting with the $O G$ application with random model.

Based on the results of the series 1 , the revised OG application with random model that will be used in the series 2 can be shown in Table 5 .

Table 5. Features Development of the OG Application

\begin{tabular}{ll}
$\begin{array}{l}\text { Features Development } \\
\text { of the OG Application }\end{array}$ & \multicolumn{1}{c}{ Explanation } \\
\hline $\begin{array}{l}\text { Profile } \\
\text { Gamification } \\
\text { Leaderboards }\end{array}$ & $\begin{array}{l}\text { Adding the ability to show the obtained rewards } \\
\text { Nothing changes } \\
\text { Nothing changes } \\
\text { Forum }\end{array}$ \\
& $\begin{array}{l}\text { This feature is used as a means of communication among the PPT and between PPT } \\
\text { and lecturers. This feature can also be used to express various challenges faced by } \\
\text { the PPT while attending the lectures } \\
\text { This feature displays the achievements of PPT' learning outcomes that have been } \\
\text { schievements Page }\end{array}$ \\
& $\begin{array}{l}\text { sorted based on the scores obtained during attending lectures using the OG } \\
\text { application. }\end{array}$ \\
\hline
\end{tabular}

\section{Series 2: Use of the OG Application with Random Model}

In general, the PPT' concept mastery in series 2 has increased after an intervention that is the use of the OG application with random model in learning interference and diffraction. The result of data processing of the pre and post-test of PPT' concept mastery is shown in Table 6.

Table 6. Pre and Post Test Results in Series 2

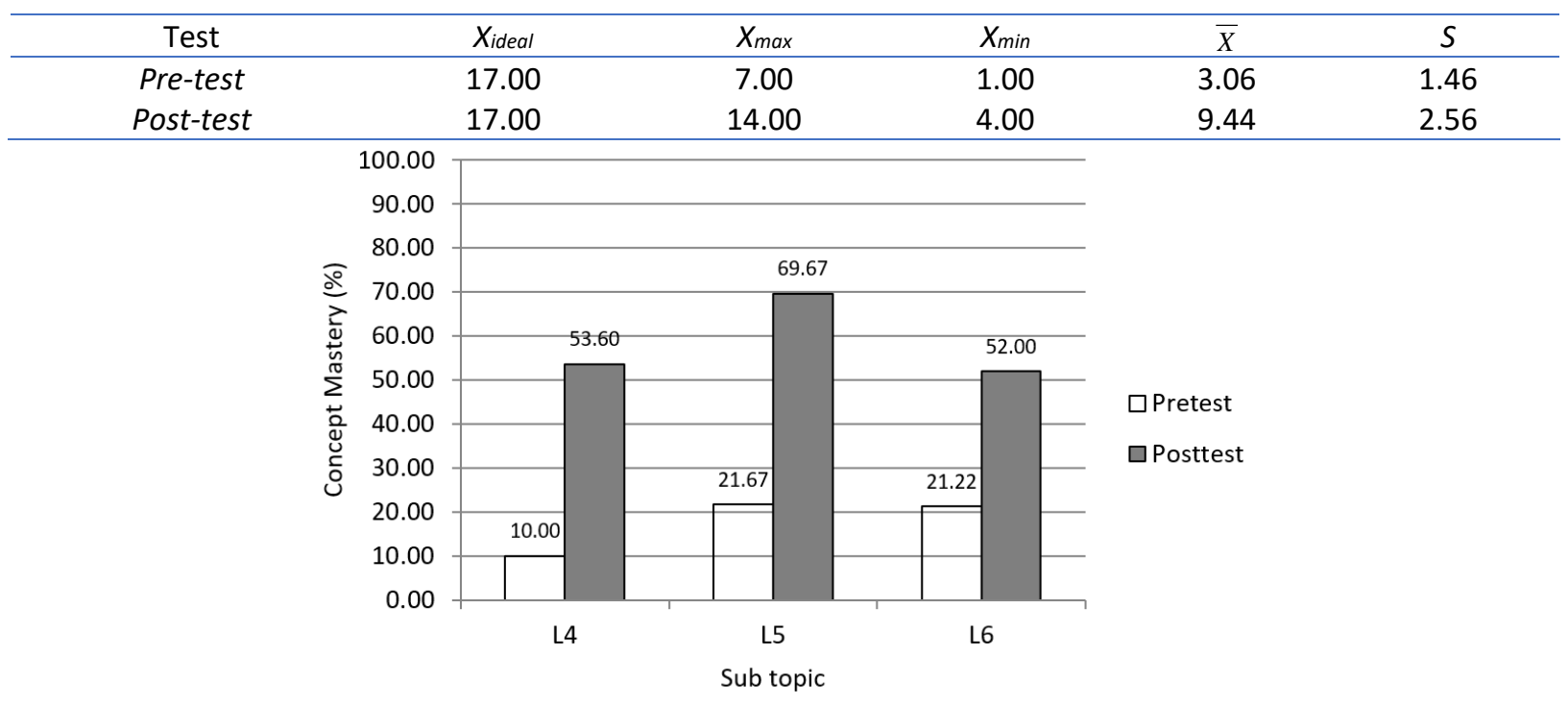

Figure 6. Profile of PPT' Concept Mastery in Series 2

Based on Figure 6, in general, PPT' concept mastery in series 2 has increased at each level. At level 4 (L4), which is the double-slit interference sub-topic (part 2), the PPT' concept mastery before the intervention was categorized as very low $(10.00 \%)$. Whereas after the intervention, the concept mastery is categorized as medium (53.60\%). This shows that there are differences in the PPT' concept mastery at level 4 of 43.60 percent. At level 5 (L5), which is the sub-topic of multiple-slit interference, PPT' concept mastery before the intervention was categorized as low (21.67\%). Whereas after the 
intervention, it was categorized as high (69.67\%). This shows that there is a difference in the concept mastery at level 5 of 48.00 percent. At level 6 (L6), which is the single-slit diffraction sub-topic, the PPT' concept mastery before the intervention was categorized as low (21.22\%). Whereas after the intervention, the concept mastery is categorized as medium $(52.00 \%)$. This shows that there are differences in concept mastery at level 6 by 30.78 percent.

\section{Revision of the OG Application with Random Model on The Series 2}

The revision of the OG application with a random model in series 2 is based on findings that can be used as an improvement, including; (1) In the OG application with random model, it is necessary to include project features to be able to administer learning activities that will be carried out by the PPT. (2) The achievement page featured in series 2 is still displayed as a whole as shown in Figure 7, which made the PPT find it difficult to find their names since all PPT who take the course are displayed on the same page. In the OG application with random model, the achievement page needs to not only display all PPT but can also be displayed per class or instances. And (3) The forum is expected to not only be able to send messages in the form of text, but also can upload images, word documents, pdfs, excels, and videos as presented in Figure 8.

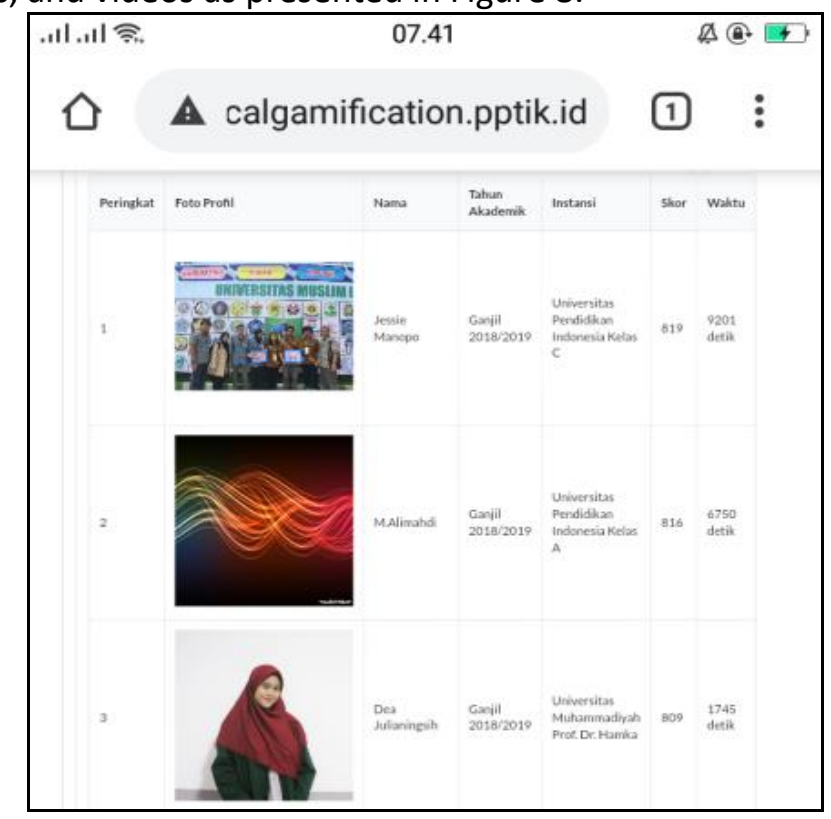

Figure 7. Achievement Page Feature in the OG Application with Random Model

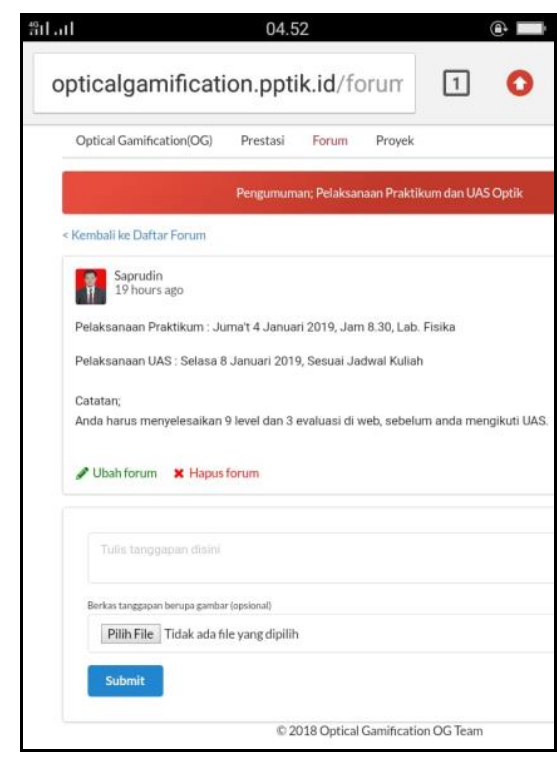

Figure 8. The Forum Feature in the OG Application with Random Model 
From the analysis result of the series 2, the revision of the OG application with random model that would be used in the series 3 is presented in Table 7 .

Table 7. Features Development of the OG Application Series 2

\begin{tabular}{|c|c|}
\hline $\begin{array}{l}\text { Features Development } \\
\text { of the OG Application }\end{array}$ & Explanation \\
\hline Profile & No changes \\
\hline Gamification & No changes \\
\hline Forum & Upload photos, word documents, Pdf, Excel, and videos \\
\hline Achievement Page & Filters per instances and per class \\
\hline Projects & $\begin{array}{l}\text { This feature is used to administer project activities carried out by PPT on the OG } \\
\text { system. }\end{array}$ \\
\hline Leaderboards & No changes \\
\hline
\end{tabular}

\section{Series 3: Use of the OG Application with Random Model}

In general, the PPT' concept mastery in series 3 was increased after the intervention in the optics course, which is the use of the OG application with random model, especially for the topics of interference and diffraction. The result of pre and post-test data of PPT' concept mastery in series 3 is shown in Table 8.

Table 8. Pre and Post Test Results in Series 3

\begin{tabular}{cccccc}
\hline Test & $X_{\text {ideal }}$ & $X_{\max }$ & $X_{\min }$ & $\bar{X}$ & $s$ \\
\hline Pre-test & 25.00 & 9.00 & 0.00 & 4.32 & 2.21 \\
Post-test & 25.00 & 20.00 & 10.00 & 15.62 & 2.41 \\
\hline
\end{tabular}

Based on Figure 9, in general, the PPT' concept mastery in series 3 has increased at each level. At level 7 (L7), which is the sub-topic of circular-aperture diffraction, PPT' concept mastery before the intervention is categorized as very low $(14.00 \%)$. Whereas after the intervention, the PPT' concept mastery is categorized as high (75.75\%). This shows that there are differences on PPT' concept mastery at level 7 of 61.75 percent.

At level 8 (L8), which is the diffraction grating sub-topic, the PPT' concept mastery before the intervention was categorized as very low (17.23\%). Whereas after the intervention, the PPT' concept mastery was increased and categorized as medium (49.31\%). This shows that there are differences in PPT' concept mastery at level 8 of 32.08 percent.

At level 9 (L9), which is the resolving power sub-topic, the PPT' concept mastery before the intervention was categorized as very low (19.13\%). Whereas after the intervention, the concept mastery is increased to the high category $(77.25 \%)$. This shows that there are differences in the PPT' concept mastery at level 9 by 58.12 percent.

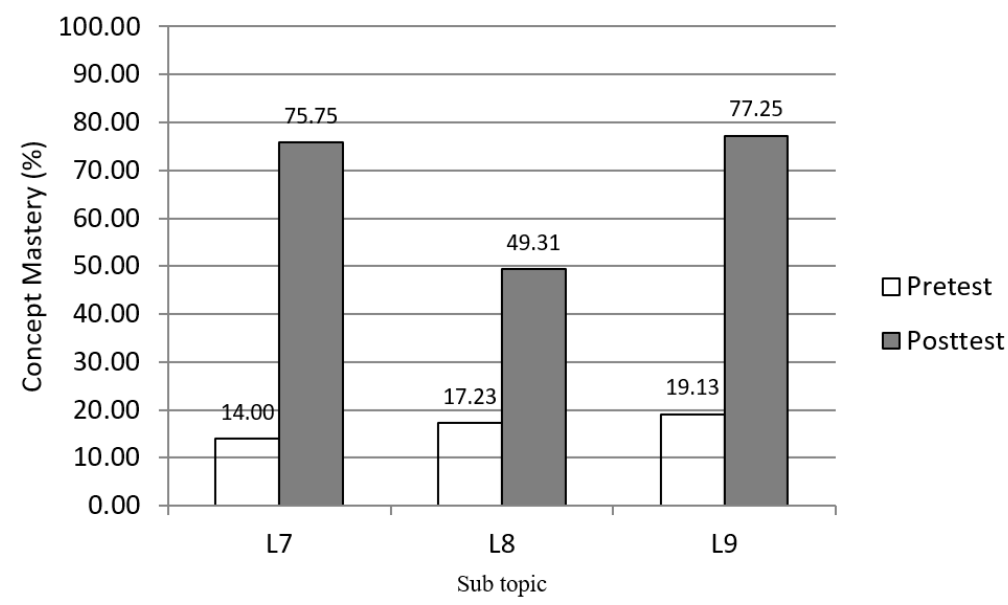

Figure 9. Profile of PPT' Concept Mastery in Series 3 
The Effectiveness of Using the OG Application with Random Model Developed to Increase the PPT' Concept Mastery

To find out the effectiveness of OG application with a random model developed to improve the PPT' concept mastery, it compared the normalized gain $\langle g\rangle$ on each series. The pattern of the normalized gain as a result of the intervention in the form of using the OG application with random model is shown in Figure 10. In general, the normalized gain $\langle g\rangle$ in series 1 through series 3 is increasing. The normalized gain $\langle g\rangle$ for each series was 0.41 (moderate), 0.46 (moderate), and 0.55 (moderate).

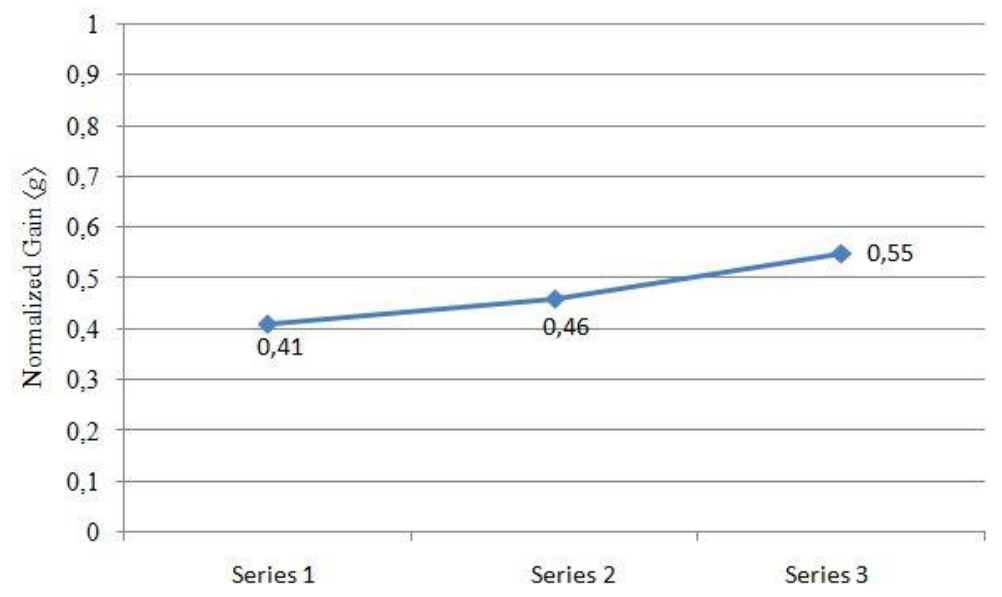

Figure 10. Normalized Gain Pattern of PPT' Concept Mastery

Based on the results of the analysis and revision that has been done, the features of the OG application with random model developed in this research are shown in Table 9.

Table 9. The Features of OG Application with a Random Model

\begin{tabular}{|c|c|}
\hline $\begin{array}{c}\text { Features of OG } \\
\text { Application }\end{array}$ & Explanation \\
\hline Profile & $\begin{array}{l}\text { This feature displays a description of PPT' data such as full names, student identification } \\
\text { numbers, instances, the portrait of the PPT who joins the class using the OG system, and } \\
\text { the obtained rewards (stars). }\end{array}$ \\
\hline Gamification & $\begin{array}{l}\text { This gamification feature is built by integrating dependent-experiment quiz, remedial } \\
\text { teaching and, mastery learning. The OG application consists of nine levels and three } \\
\text { evaluations. }\end{array}$ \\
\hline Forum & $\begin{array}{l}\text { This feature is used as a means of communication among the PPT and between the PPT } \\
\text { and the lecturers. This feature can also be used by the PPT to express various challenges } \\
\text { they faced while attending the lectures using the OG system. The PPT can upload photo, } \\
\text { word document, pdf, excel, and video files. }\end{array}$ \\
\hline Achievements & This feature displays the PPT' learning outcomes that have been sorted based on the scores \\
\hline Page & $\begin{array}{l}\text { obtained while attending the lectures program using the OG system. The achievement } \\
\text { page can also be displayed and sorted per instance and class. }\end{array}$ \\
\hline Projects & $\begin{array}{l}\text { This feature is used to administer project activities for the PPT to work on the OG system. } \\
\text { The PPT can upload photo, word document, pdf, excel, and video files. }\end{array}$ \\
\hline Leaderboards & $\begin{array}{l}\text { This feature displays the ten PPT with the highest score among all PPT who take classes } \\
\text { using the OG system. }\end{array}$ \\
\hline
\end{tabular}

\section{Conclusion}

Based on the analysis of the obtained research data, several conclusions could be generated as follows: (1) The OG application with random model that has been developed has several features such as profile, gamification, forum, achievement page, project, and leaderboards; (2) The OG application with random model has been proven to be successful in providing freedom of access for the PPT to be able to work on the given learning tasks, for both the levels (sub-topics) and the 
evaluations, in sessions and sequences that can be done randomly to their likings; (3) The result of preliminary field testing of using the OG with random model shows that PPT' concept mastery has increased from series 1 to the next following series.

\section{References}

Agustine, D., Wiyono, K., \& Muslim, M. (2014). Pengembangan e-learning berbantuan virtual laboratory untuk mata kuliah praktikum fisika dasar II di Program Studi Pendidikan Fisika FKIP UNSRI. Jurnal Inovasi Dan Pembelajaran Fisika, 1(1), 33-43.

https://doi.org/10.36706/jipf.v1i1.1218

Alrsa'i, M. S., \& Aldhamit, Y. ahmed. (2014). The effect of computer simulation on Al-Hussein Bin Talal University $S$ tudent ' $s$ understanding of electricity and magnetism concepts and their attitudes towared physics learning. International Journal of Educational Research and Technology IJERT, 5(1), 54-60.

Alsultanny, Y. A., Nouby, A. M., \& Al-Enazi, T. T. (2014). Effects of using simulation in e-learning programs on misconceptions and motivations towards learning. International Journal of Science and Technology Education Research, 5(3), 40-51. https://doi.org/10.5897/IJSTER2010.043

Aminoto, T., \& Pathoni, H. (2014). Penerapan media e-learning berbasis schoology untuk meningkatkan aktivitas dan hasil belajar materi usaha dan energi di kelas XI SMAN 10 kota Jambi. Sainmatika: Jurnal Sains Dan Matematika Universitas Jambi, 8(1), 13-29.

Amri, I., Syuhendri, S., \& Wiyono, K. (2015). Pengembangan media pembelajaran e-learning berbasis web untuk mata kuliah pendahuluan fisika inti. Jurnal Inovasi Dan Pembelajaran Fisika, 2(1), 25-35. https://doi.org/10.36706/jipf.v2i1.2351

Arif, Z. (2012). Andragogi. Angkasa.

Chen, C.-L. D., Yeh, T.-K., \& Chang, C.-Y. (2016). The effects of game-based learning and anticipation of a test on the learning outcomes of 10th grade geology students. EURASIA Journal of Mathematics, Science and Technology Education, 12(5), 1379-1388. https://doi.org/10.12973/eurasia.2016.1519a

Collier, L., Dunham, S., Braun, M. W., \& O'Loughlin, V. D. (2012). Optical versus virtual: Teaching assistant perceptions of the use of virtual microscopy in an undergraduate human anatomy course. Anatomical Sciences Education, 5(1), 10-19. https://doi.org/10.1002/ase.262

Deterding, S., Antin, J., Paharia, R., \& Lawley, E. (2012). Gamification: Designing for motivation. Interactions, 19(4), 14-17. https://doi.org/10.1145/2212877.2212883

Deterding, S., Dixon, D., Khaled, R., \& Nacke, L. (2011). From game design elements to gamefulness. Proceedings of the 15th International Academic MindTrek Conference on Envisioning Future Media Environments - MindTrek'11, 9. https://doi.org/10.1145/2181037.2181040

Dharma, A. D. S. (2015). Keberagaman pengaturan batas usia dewasa seseorang untuk melakukan perbuatan hukum dalam peraturan perundang-undangan di Indonesia. Repertorium, 2(2), 2355-2646.

Dorji, U., Panjaburee, P., \& Srisawasdi, N. (2015). A learning cycle approach to developing educational computer game for improving students' learning and awareness in electric energy consumption and conservation. Educational Technology and Society, 18(1), 91-105.

Escobar, J. H., Sánchez, H., Beltrán, J. R., la Hoz, J. De, \& González, J. D. (2016). Virtual experimentation in electromagnetism, mechanics and optics: web-based learning. Journal of Physics: Conference Series, 687(1), 012078. https://doi.org/10.1088/1742-6596/687/1/012078

Gero, A., Zoabi, W., \& Sabag, N. (2014). Animation based learning of electronic devices. Advances in Engineering Education, 4(1), 1-21.

Hake, R. R. (1998). Interactive-engagement versus traditional methods: A six-thousand-student survey of mechanics test data for introductory physics courses. American Journal of Physics, 
66(1), 64-74. https://doi.org/10.1119/1.18809

Hamari, J., Shernoff, D. J., Rowe, E., Coller, B., Asbell-Clarke, J., \& Edwards, T. (2016). Challenging games help students learn: An empirical study on engagement, flow and immersion in gamebased learning. Computers in Human Behavior, 54, 170-179. https://doi.org/10.1016/j.chb.2015.07.045

Huotari, K., \& Hamari, J. (2012). Defining gamification - a service marketing perspective. Proceeding of the 16th International Academic MindTrek Conference - MindTrek'12, 17-22. https://doi.org/10.1145/2393132.2393137

Kapp, K. M., Blair, L., \& Mesch, R. (2014). The gamification of learning and instruction fieldbook: Ideas into practice. John Wiley \& Sons.

Komarudin, U., Sihaan, S. M., \& Sudirman. (2014). Developing interactive multimedia for physics learning simulation model of gas kinetic theory for senior high school students grade XI. The Second South East Asia Design/ Development Research (SEA-DR) International Conference, April, 348-357.

Martínez, G., Naranjo, F. L., Pérez, A. L., Suero, M. I., \& Pardo, P. J. (2011). Comparative study of the effectiveness of three learning environments: Hyper-realistic virtual simulations, traditional schematic simulations and traditional laboratory. Physical Review Special Topics-Physics Education Research, 7(2), 020111. https://doi.org/10.1103/PhysRevSTPER.7.020111

Marwah, S., \& Kustijono, R. (2015). Penerapan pembelajaran fisika berbasis e-learning pada materi pokok fluida statis. Jurnal Inovasi Pendidikan Fisika (JIPF), 04(02), 16-22. https://jurnal.unesa.ac.id/index.php/inovasi-pendidikan-fisika/article/view/12293

Mešić, V., Dervić, D., Gazibegović-Busuladžić, A., Salibašic, D., \& Erceg, N. (2015). Comparing the impact of dynamic and static media on students' learning of one-dimensional kinematics. Eurasia Journal of Mathematics, Science and Technology Education, 11(5), 1119-1140. https://doi.org/10.12973/eurasia.2015.1385a

Mukarom, Z., \& Rusdiana, A. (2017). Komunikasi dan teknologi informasi pendidikan. Pustaka Setia Bandung.

Mulyana, A., Hindersah, H., \& Prihatmanto, A. S. (2016). Gamification design of traffic data collection through social reporting. Proceedings of the 2015 4th International Conference on Interactive Digital Media, ICIDM 2015, Icidm. https://doi.org/10.1109/IDM.2015.7516315

Munir. (2012). Pembelajaran Jarak Jauh Berbasis Teknologi Informasi dan Komunikasi. Alfabeta.

Munir, M. (2008). Kurikulum berbasis teknologi informasi dan komunikasi. Alfabeta.

Onorato, P., Malgieri, M., \& De Ambrosis, A. (2015). Rolling motion: Experiments and simulations focusing on sliding friction forces. In Nuovo Cimento C-Colloquia And Communications In Physics, 38(3), 1-10. https://doi.org/10.1393/ncc/i2015-15107-1

Putra, P. D. A., \& Sudarti. (2015). Real life video evaluation with e-learning system to improve critical thinking skills student. Jurnal Kependidikan, 45(1), 76-89.

Putri, W. M., Bakri, F., \& Permana, A. H. (2016). Pengembangan media pembelajaran berbasis multimedia augmented reality pada pokok bahasan alat optik. Prosiding Seminar Nasional Fisika (E-Journal) SNF2016 UNJ, V, SNF2016-RND-83-SNF2016-RND-88. https://doi.org/10.21009/0305010218

Radlovic-Cubrilo, D., Lozanov-Crvenkovic, Z., Obadovic, D., \& Segedinac, M. (2014). The application of multimedia and its effects on teaching physics in secondary school. Zbornik Instituta Za Pedagoska Istrazivanja, 46(2), 339-363. https://doi.org/10.2298/ZIPI1402339R

Saprudin, S. (2018). Analisis kesiapan dan strategi monitoring evaluasi program pengembangan perkuliahan gelombang dan optik berbasis game. JIPFRI (Jurnal Inovasi Pendidikan Fisika Dan Riset Ilmiah), 2(1), 28-37. https://doi.org/10.30599/jipfri.v2i1.207

Saprudin, S. (2015). Efektivitas penerapan model kooperatif STAD berbasis multimedia untuk 
meningkatkan penguasaan siswa SMA terhadap kemampuan yang diujinasionalkan mata pelajaran fisika di Maluku Utara. ProsidingSNIPS2015, 529-533.

https://doi.org/10.31219/osf.io/jfx9d

Saprudin, S., Abdullah, I. H., Haerullah, A., \& Saraha, A. R. (2016). Pengembangan media video tutorial model pembelajaran berbasis masalah pada materi kalor. EDUKASI, 14(2), 451-461. https://doi.org/10.33387/j.edu.v14i2.209

Saprudin, S., Haerullah, A. H., Abdullah, I. H., Saraha, A. R., \& Hamid, F. (2018). Pengembangan media video tutorial model discovery learning materi tekanan hidrostatis. Prosiding Seminar Kontribusi Fisika 2017, 300-304. https://doi.org/10.31219/osf.io/9nxtq

Saprudin, S., \& Hamid, F. (2018a). Efektivitas penggunaan multimedia interaktif materi kalor berorientasi peta kompetensi siswa sekolah menengah atas. Titian Ilmu: Jurnal Ilmiah Multi Sciences, 10(1), 29-38. https://doi.org/10.30599/jti.v10i1.135

Saprudin, S., \& Hamid, F. (2018b). Penggunaan multimedia interaktif model drill and practice materi fluida dinamis untuk meningkatkan penguasaan konsep siswa sekolah menengah atas (SMA). Prosiding Seminar Nasional Fisika (E-Journal) SNF2018 UNJ, 7, SNF2018-PE-144-SNF2018-PE151. https://doi.org/10.21009/03.SNF2018.01.PE.19

Saprudin, S., Liliasari, L., \& Prihatmanto, A. S. (2017). Pre-service physics teachers' concept mastery and the challenges of game development on physics learning. Journal of Physics: Conference Series, 895(1), 012109. https://doi.org/10.1088/1742-6596/895/1/012109

Saprudin, S., Liliasari, L., Prihatmanto, A. S., \& Setiawan, A. (2019). The potential of gamification in developing pre-service physics teachers' critical and creative thinking skills. Omega: Jurnal Fisika Dan Pendidikan Fisika, 5(1), 7. https://doi.org/10.31758/OmegaJPhysPhysEduc.v5i1.7

Saprudin, S., Liliasari, L., Prihatmanto, A. S., Setiawan, A., \& Hamid, F. (2020). Desain dan uji coba penggunaan optical gamification (OG) model serial untuk meningkatkan keterampilan berpikir kritis mahasiswa. Jurnal Pedagogi Dan Pembelajaran, 3(3), 483-498. https://doi.org/10.23887/jp2.v3i3.29120

Saprudin, S., Liliasari, L., Setiawan, A., \& Prihatmanto, A. S. (2019). The effectiveness of using digital game towards students' academic achievement in small and large classes: A comparative research. International Journal of Learning, Teaching and Educational Research, 18(12), 196210. https://doi.org/10.26803/ijlter.18.12.12

Saprudin, S., Liliasari, L., Setiawan, A., \& Prihatmanto, A. S. (2020). Optical Gamification (OG); Serial versus random model to improve pre-service physics teachers' concept mastery. International Journal of Emerging Technologies in Learning (IJET), 15(09), 39. https://doi.org/10.3991/ijet.v15i09.11779

Srisawasdi, N., \& Kroothkeaw, S. (2014). Supporting students' conceptual development of light refraction by simulation-based open inquiry with dual-situated learning model. Journal of Computers in Education, 1(1), 49-79. https://doi.org/10.1007/s40692-014-0005-y

Su, K. D., \& Yeh, S. C. (2014). Effective assessments of integrated animations--exploring dynamic physics instruction for college students' learning and attitudes. Turkish Online Journal of Educational Technology-TOJET, 13(1), 89-99.

Tarno, H. (2017). Pendidikan orang dewasa (POD). Gava Media.

Tsai, M. J., Huang, L. J., Hou, H. T., Hsu, C. Y., \& Chiou, G. L. (2016). Visual behavior, flow and achievement in game-based learning. Computers and Education, 98, 115-129. https://doi.org/10.1016/j.compedu.2016.03.011

Yang, J. C., Lin, Y. L., \& Liu, Y. C. (2016). Effects of locus of control on behavioral intention and learning performance of energy knowledge in game-based learning. Environmental Education Research, 23(6), 886-899. https://doi.org/10.1080/13504622.2016.1214865

Yuda, I. G. N. H., Suma, K., \& Candiasa, I. M. (2014). Pengembangan e-learning fisika dalam bentuk 
Momentum: Physics Education Journal, 5 (1), 2021, 42

Saprudin Saprudin et al

website berorientasi sains teknologi masyarakat untuk meningkatkan penguasaan konsep dan kreativitas siswa kelas XI IPA. Jurnal Pendidikan Dan Pembelajaran IPA Indonesia, 4(1).

Zhou, M.-C., Chen, Y., \& Zhao, Q. (2017). Mobile internet and technology for optical teaching reform in higher education. Education and Training in Optics and Photonics (p. 104525K). Optical Society of America. https://doi.org/10.1117/12.2269762 